\title{
PENGARUH STRATEGI PEMASARAN DAN KUALITAS PELAYANAN TERHADAP PENINGKATAN PENJUALAN DI PT. AYU INDAH GROUP CABANG PACIRAN LAMONGAN
}

\author{
M. Hafidh Nasrullah ${ }^{1}$ \\ Muhammad Faizin ${ }^{2}$ \\ Fakultas Ekonomi Universitas Islam Darul 'Ulum Lamongan \\ Email : hafidh@unisda.ac.id
}

\begin{abstract}
The problem that is known to be related to customer loyality in the PT. Ayu Indah Lamongan is the fluctuation in sales in the past three months. This study aims to influence Strategy marketing and Quality of service on Increased sales in the PT. Ayu Indah Lamongan which is on Jl. Raya Deadles No. 35, Paciran, Lamongan. This research is a survey with quantitative research, population and sample of this study were 60 respondents who bought airplane, car rental etc. in the PT. Ayu Indah Lamongan, data colllection using interviews and questionnaires. Analysis of the data used is the validity test, multiple linear regression analysis, hypothesis testing and the coefficient of determination $R^{2}$ test.
\end{abstract}

Keywords : Strategy marketing, Quality of service and Increased sales

Abstrak : Permasalahan yang diketahui berkaitan dengan peningkatan pembelian di PT. Ayu Indah Group Paciran Lamongan adalah terjadi fluktuasi penjualan dalam kurun tiga bulan terakhir. Penelitian ini bertujuan untuk mengetahui pengaruh strategi pemasaran dan kualitas pelayanan peningkatan penjualan di PT. Ayu Indah Group Paciran Lamongan yang ada di Jl. Raya Deadles No. 35, Paciran, Lamongan. Penelitian ini bersifat survey dengan penelitian kuantitatif, populasi dan sampel penelitian ini adalah 60 responden yang membeli tiket pesawat, pasport, sewa mobil dan lain-lain di PT. Ayu Indah Group Paciran Lamongan Teknik pengumpulan data menggunakan wawancara dan kuesioner. Analisis data yang digunakan adalah uji validitas, uji reliabilitas, uji asumsi klasik, analisis regresi linier berganda, uji hipotesis serta uji koefisien determinasi $R^{2}$.

Kata Kunci : Strategi Pemasaran, kualitas pelayanan dan peningkatan penjualan

\section{PENDAHULUAN}

PT. Ayu Indah Group Cabang Paciran adalah satu dari sekian banyak perusahaan yang bergerak dalam dalam sektor tour and travel bisa dikatakan jenis usaha kecil menengah yang dapat menentukan perkembangan perekonomian bangsa juga bisa mengurangi pengangguran yang terjadi selama ini, terutama di sekitar Kecamatan Paciran Lamongan. Perusahaan ini melayani berbagai macam jasa salah satunya adalah menjual tiket pesawat dari berbagai macam maskapai pesawat baik domestik maupun internasional.

Perusahaan yang bergerak dibidang yang sejenis di Kecamatan Paciran Lamongan yang menjadi pesaing bagi PT. Ayu Indah Group diantaranya adalah PT. Arifin Sidayu, PT. Merpati Indah dan CV. Jaya Indah yang tentu saja pesaingpesaing tersebut memiliki strategi bisnis tersendiri yang tentu menjadi ancaman yang perlu dipertimbangkan. Namun PT. Ayu Indah Group memiliki strategi pemasaran yang berbeda dari para 
pesaing-pesaingnya yaitu lebih menekankan dan menitik beratkan pada strategi pemasaran dan kualitas pelayanan yang diberikan. Dalam hal ini strategi kualitas pelayanan mencakup beberapa strategi yang masuk dalam 4P : Pertama adalah Produk, produk biasanya berupa apa aja yang ditawarkan kepada pelangganpotensial untuk memenuhi keinginan dan kebutuhan tertentu. Pengembangan produk dapat dilakaukan setalah menganalisa kebutuhan dari keinginan pasarnya yang di dapat salah satunya dengan riset pasar.

Yang kedua adalah Harga (Price), disemua produk dan jasa yang ada sekarang ini, strategi pemasaran yang tepat dapat meningkatkan harga pokok dan harga jual produk. Faktor faktor yang perlu dipertimbangkan dalam suatu pentapan harga antara lain biaya,keuntungan, harga yang ditetapkan oleh pesaing dan perubahan keinginan pasar. Yang ketiga adalah Promosi (Promotion), Adapun yang termasuk dalam kegiatan promosi adalah promosi jasa/produk, promosi penjualan, dan publisitas. Promosi disini terkait dengan besaran biaya promosi dan kegiatan promosi yang akan dilakukan. Tujuan diharapkan dari promosi adalah konsumen dapat mengetahui tentang produk tersebut. Yang keempat adalah: Place (Tempat) yaitu pendistribusian produk yang sudah ada, harus di distribusikan kepada konsumen atau pengguna. Proses untuk hal ini yaitu produk dipindahkan dari produsen ke konsumen melalui saluran distribusi. Bila perusahaan dapat melakukannya tanpa bantuan perantara, maka perantara jelas tidak diperlukan. Namun kenyatannya adalah bahwa perantara menyediakan satu mata rantai penting pada seluruh proses pemasaran.

Atep Adya Barata (2013:36) kualitas Pelayanan adalah ukuran pelayanan yang ditentukan oleh pihak yang dilayani berdasrkan harapan-harapn mereka dalam memenuhi kepuasannya. Pelanggan memiliki persepsi tentang perusahaan mengenai pengalaman yang diterima komsumen sehingga mereka mengetahui bagaimana pelayanan yang didapat PT Ayu Indah Group Cabang Paciran Lamongan tersebut tidak sesuai dengan harapan konsumen.

Di era modern seperti sekarang ini persaingan pasar yang semakin bervariasi dan sangat kompetitif, maka akan sangat diperlukan suatu pemikiran dan terobosan baru yang bisa menimbulkan apapun yang disukai oleh para pembeli atau konsumen untuk memilih dan tertarik dengan produk ataupun jasa yang ditawarkan. Dalam hal ini perusahaan dituntut agar dapat menjalankan operasional dengan baik dan selalu memberikan inovasi yang baru terhadap para konsumen, sehingga perusahaan tersebut dapat tetap beroperasi dan bertahan dalam persaingan usaha dalam jangka waktu yang relatif lama. Banyak perusahaan yang memeberikan kreasi-kreasi baru untuk mengatasi persaingan dengan perusahaan yang bergerak dibidang yang sama.

Sebagai perusahaan yang bergerak dibidang yang sama yakni travel harus saling berlomba dan berinovasi dalam berbagai hal agar dapat mempertahankan eksistensi dan kepercayaan para konsumen. Didalam bisnis, persaingan pasar bukan sekedar melihat kompetitor yang lebih besar saja, tetapi juga harus melihat dan mempertimbangkan pesaing yang level nya masih lebih kecil dari perusahaan yaitu perusahaan yang baru berdiri, karena para pesaing tersebut bisa saja mengambil konsumen yang suka untuk memperbandingkan perusahaan baru dengan perusahaan yang sudah lama bergerak, yang tentu saja dapat mengakibatkan kurang nya konsumen dan dapat menurunkan tingkat pasar yang diperoleh dari perusahaan maka akan berpengaruh di proses penjualan yang 
dapat mengakibatkan profit yang semakin menurun.

Dengan banyaknya usaha-usaha kecil yang bergerak dalam bidang yang sama menyebabkan ketat nya persaingan membuat pengusaha yang lebih unggul di tuntut agar membuat produk-produk baru dan inovasi yang lebih menarik sehingga tetap dapat berjalan menghadapi persaingan usaha tersebut. Oleh karena itu, penyesuaian dari para pengusha pada perkembangan keadaan wajib diperlukan untuk menghadapi ketatnya persaingan tersebut, sangat diperlukan untuk membuat manajemen suatu strategi yang baik sehingga para pengusaha bisa mengantisipasi dampak oleh suatu kejadian dan tetap mampu bersaing. Kelebihan agar dapat mempertahankan dan meningkatkan kemampuan bersaing sesama jenis usaha bisa dilakukan dengan cara menerapkan strategi pemasaran dan kualitas pelayanan yang baik.

Strategi pemasaran yang baik, bisa dapat dilihat dari kemampuannya dalam meningkatkan penjualan atau omzet mereka dalam satu periode sesuai dengan jumlah/ kualitas jasa dan produk yang dihasilkan oleh perusahaan tersebut. Oleh karena itu manager dan para karyawan diwajibkan untuk membuat sebuah strategi baru dan dapat memanfaatkan berbagai kesempatan yang ada juga berusaha mengurangi resiko-resiko yang ada dan menjadi suatu kesempatan.

PT. Ayu Indah Group Cabang Paciran yang beroperasi pada bidang tour and travel adalah perusahaan dapat dikatakan perusahaan kecil menengah, pada umumnya perusahaan yang beroperasi pada bidang tour and travel bangkrut dikarenakan persaingan yang ketat ini. Penyebabnya adalah kurang tepatnya strategi pemasaran yang dilakukan oleh para manajer dan karyawan perusahaan, terutama strategi bisnis yang tepat yang bisa menentukan seberapa besar penjualan yang bisa meningkatkan keuntungan perusahaan. Oleh karena itu perusahaan yang bergerak dibidang ini dituntut untuk menggunakan strategi yang tepat untuk mempertahankan kelangsungan usahanya.

Di era kemajuan pembangunan ekonomi negra indonesia para usaha kecil selalu dilihat sebagai sektor usaha yang mempunyai peranan penting karena sebagian besar jumlah penduduknya memiliki pendidikan yang belum tinggi dan hidup di kegiatan usaha kecil baik di sektor modern dan tradisional. Usaha kecil adalah salah satu bagian yang sangat penting untuk perekonomian negara indonesia karena usaha kecil dapat membuka lowongan-lowongan pekerjaan yang banyak di berbagai bidang usaha sehingga masyarakat mulai memikirkan untuk bisa mendirikan dan menjalankan usaha kecil yang memiliki prospek yang bagus di masa yang akan datang.

Saat ini didalam perkembangan perekonomian negara indonesia seperti pada saat ini, maju tidaknya tidak luput dari peran banyaknya para usaha kecil yang semakin berkembang dan juga para usaha kecil yang mengalami kerugian, semua itu tergantung oleh kebijakankebijakan pemerintah yang baru untuk bisa mengatur dan memberikan bantuan dalam hal apapun sehingga menjadi usaha kecil yang dapat meningkatkan pendapatan perkapita penduduknya serta dapat mengurangi jumlah dari angka pengangguran.

\section{TINJAUAN PUSTAKA}

\section{Strategi Pemasaran}

Menurut Sofjan Assauri (2017:3), strategi pemasaran pada dasarnya adalah rencana yang menyeluruh, terpadu dan menyatu di bidang pemasaran, yang memberikan panduan tentang kegiatan yang akan dijalankan untuk dapat tercapainya tujuan pemasaran suatu perusahaan. Dengan kata lain, strategi pemasaran adalah 
serangkaian tujuan dan sasaran, kebijakan dan aturab yang memberi arah kepada usaha-usaha pemasaran perusahaan dari waktu ke waktu, pada masing-masing tingkatan dan acuan serta alokasinya, terutama sebagai tanggapan peruahaan dalam menghadapi lingkungan dan keadaan lingkungan yang selalu berubah. Oleh karena itu, perancangan strategi pemasaran harus didasarkan atas analisis lingkungan dan internal perusahaan melalui analisis keunggulan dan kelemahan perusahaan, serta analisis kesempatan dan ancaman yang dihadapi perusahaan dari lingkungannya.

Menurut Fandy Tjiptono (2014:41) Bauran pemasaran (marketing mix) adalah sebagai alat pemasarn taktis yang dapat di kendalikan yang di padukan oleh perusahaan untuk menghasilkan respon yang diinginkan dalam pasar sasaran. Dalam strategi pemasaran hendaknya perusahaan mempersiapkan perencanaan yang terperinci mengenai bauran pemasaran. Kothler mendefinisikan bahwa bauran pemasaran adalah kelompok alat pemasaran yang di gunakan perusahaan untuk mencapai sasaran pemasarannya dalam pasar sasaran.

Dari definisi diatas dapat diambil suatu kesimpulan secara umum, bahwa bauran pemasaran (marketing mix) terdiri dari empat variabel yang dikenal dengan 4P yaitu produk (product), harga (price), promosi (promotion) dan tempat (place).

\section{Kualitas pelayanan}

Menurut Mardo (2016:25)

kualitas Pelayanan adalah merupakan suatu skala atau ukuran bagi perusahaan untuk mengukur seberapa banyak perusahaan berhasil memberikan solusi pada permasalahan pelanggan. Pelanggan memiliki persepsi tentang perusahaan, mengenai pengalaman mereka dalam menerima Pelayanan dari perusahaan, apakah sesuai dengan harapan pelanggan atau tidak.

Menurut Tjiptono (dalam Sarini Kodu 2013:1253) kualitas Pelayanan merupakan isu krusial bagi setiap perusahaan, apapun bentuk produk yang dihasilkan kualitas Pelayanan secara sederhana bisa diartikan sebagai ukuran seberapa tingkat Pelayanan yang diberikan mampu sesuai dengan ekspetasi pelanggan.

Menurut Mardo (2016:31) untuk mengetahui kualitas Pelayanan yang dirasakan secara nyata oleh pelanggan. Adapun indikator ukuran kualitas Pelayanan yang terletak pada 5 (lima) dimensi yaitu :

1) Tangibles (kualitas Pelayanan yang berupa sarana fisik perkantoran, komputerisasi administrasi, ruang tunggu, tempat informasi dan sebagainya)

2) Reliability (kemampuan dan keandalan untuk menyediakan Pelayanan yang terpercaya)

3) Responsiveness (kesanggupan untuk membantu menyediakan Pelayanan secara cepat dan tepat, serta tanggap terjadap keinginan pelanggan)

4) Assurance (kemampuan dan keramahan, serta sopan santun pegawai dalam meyakinkan kepercayaan pelanggan)

5) Emphaty (sikap tegas tetapi perhatian dari pegawai terhadap pelanggan)

\section{Penjualan}

Menurut Basu Swastha (2018:8) Definisi penjualan ini cukup luas. Beberapa ahli menyebutnya sebagai ilmu dan beberapa yang lain menyebutnya sebagai seni. Ada pula yang memasukkan masalah etik dalam 
penjualan. Pada pokok nya, istilah menjual dapat diartikan sebagai berikut;

Menjual adalah ilmu dan seni mempengaruhi pribadi yang di lakukan oleh penjual untuk mengajak orang lain agar bersedia membeli barang ataupun jasa yang di tawarkannya.

Jadi, adanya penjualan dapat tercipta suatu proses pertukaran barang/jasa antara penjual dan pembeli. Didalam proses perekonomian kita ekonomi uang, seseorang yang menjual sesuatu akan mendapatkan imbalan berupa uang. dengan alat penukar berupa uang, orang akan lebih mudah memenuhi segala keinginannya. Dan penjualan menjadi lebih mudah dilakukan. Jarak yang jauh jarak yang jauh tidak menjadi masalah bagi penjual. Indikator-indikator yang mempengaruhi adanya penjualan, antara lain :

1. Kondisi dan kemampuan penjual

Transaksi jual beli atau memindahkan hak milik secara mersial atas barang dan jasa itu pada prinsipnya melibatkan dua pihak, yaitu penjual sebagai pihak pertama dan pembeli sebagai pihak kedua. Disini penjual harus bisa meyakinkan kepada pembelinya agar dapat mencapai sasaran penjualan yang diinginkan.

2. 2. kondisi pasar

Pasar, sebagai kelompok pembeli dan atau pihak yang menjadi sasaranya dalam penjualan, dapat pula mempengaruhi kegiatan penjualanya.

\section{3. Modal}

Akan lebih sulit bagi penjual untuk menjual barangnya apakah barang yang dijual tersebut belum dikenal oleh calon pembeli atau apabila lokasi pembeli jauh dari tempat penjual. Dalam keadaan seperti ini penjual harus memperkenalkan dulu atau membawa barangnya ketempat pembeli. Untuk melaksanakan maksud tersebut diperlukan adanya sarana serta usaha, seperti : alat transport, tempat peragaan baik didalam perusahaan maupun diluar perusahaan, usaha promosi dan sebagainya.

4. Kondisi organisasi perusahaan

Pada perusahaan besar, biasanya masalah penjualan ini ditanggani oleh bagian tersendiri (bagian penjualan) yang dipegang oleh orang-orang tertentu/ahli dibidang penjualan. Lain halnya dengan perusahaan kecil dimana masalah perusahaan ditangani oleh orang yang juga melakukan fungsifungsi lain. Hal ini disebabkan karena jumlah tenaga kerjanya yang sedikit, sistem organisasinya lebih sederhana, masalah yang dihadapi serta sarana yang dimilikinya tidak sekompleks perusahaan besar. Biasanya, biasanya masalah penjualan ini ditangani oleh pimpinan dan tidak diberikan kepada orang lain.

5. faktor-faktor lain

Faktor-faktor lain seperti: periklanan, peragaan, kampanye, pemberian hadiah sering mempengaruhi penjualan. Namun untuk melaksanakanya, diperlukan sejumlah dana yang tidak sedikit. Bagi perusahaan yang bermodal kuat, kegiatan ini secara rutin dapat dilakukan. Sedangkan bagi perusahaan kecil yang mempunyai modal relatif kecil, kegiatan ini jarang dilakukan.

\section{METODE PENELITIAN Sejarah Singkat Perusahaan}

PT. Ayu Indah Group merupakan perusahaan yang bergerak pada bidang tour dan travel ini berdiri pada tanggal 22 Juni 2009, didirikan oleh pemiliknya sendiri yaitu Bapak H. Muhammad Ahyat, SE. yang otomatis telah membantu pemerintah untuk menyediakan lowongan kerja dengan berorientasi pada kesejahteraan perekonomian masyarakat sekitar. 
Sejalan dengan tujuan dan melihat lingkungan sekitar adalah tenaga kerja Indonesia yang bekerja diluar negeri sehingga didirikanlah perusahaan PT. Ayu Indah Group tour and travel sebagai penyedia layanan pemesanan tiket, membantu mendapatkan visa luar negeri (bekerjasama dengan BP2TKI) serta memberikan layanan antar jemput dari dan ke bandara (Juanda), juga melayani penyewaan kendaraan seperti mobil dan bus (rent car). Dan jasa pembuatan paspor.

\section{Pendekatan Penelitian}

Jenis penelitian ini adalah penelitian kuantitatif. Menurut Sugiyono (2018:7) metode kuantitatif dinamakan metode tradisional, karena metode ini sudah cukup lama digunakan sehingga sudah menstradisi sebagai metode untuk penelitian. Metode ini disebut sebagai metode positivistik karena berlandaskan pada filsafat positivisme. Metode ini sebagai metode ilmiah/scientific karena telah memenuhi kaidah-kaidah ilmiah yaitu konkrit/empiris, obyektif, terukur, rasional, dan sistematis. Metode ini juga disebut metode discovery, karena dengan metode ini dapat ditemukan dan dikembangkan berbagai iptek baru. Metode ini disebut metode kuantitatif karena data penelitian berupa angkaangka dan analisis menggunakan statistik.

\section{Tempat Dan Waktu Penelitian}

Adapun waktu yang digunakan oleh penulis dalam melakukan penelitian baik mulai pengajuan judul, survey sampai pada akhir penelitian skripsi adalah mulai bulan Nopember 2019 sampai dengan bulan juni 2020 . Sedangkan lokasi penelitian adalah di perusahaan PT. Ayu Indah Group Cabang Paciran Lamongan yang terletak di Jl. Deandels No. 35, Paciran, Kecamatan Paciran, Kabupaten Lamongan.

\section{Obyek Penelitian}

objek Penelitian ini adalah tentang strategi pemasaran dan kualitas pelayanan sedangkan subjeknya seberapa besar pengaruh terhadap meningkatkan penjualan di PT. Ayu Indah Group Cabang Paciran Lamongan Lamongan.

\section{HASIL DAN PEMBAHASAN}

\section{Uji Validitas}

Untuk mengukur validitas dapat dilakukan dengan membandingkan nilai $r_{\text {hitung }}$ dengan $r_{\text {tabel. }}$ Jika $r_{\text {hitung }}>$ $\mathrm{r}_{\text {tabel }}$ maka butir atau pertanyaan atau indikator tersebut dinyatakan valid. Ditemukan nilai $r_{\text {tabel }}$ dengan $\mathrm{N}=98$ pada signifikan 0,05 diperoleh sebesar 0,165

\section{Hasil Analisis Variabel Strategi Pemasaran (X1)}

\begin{tabular}{|c|c|c|c|}
\hline Item & $\mathbf{r}_{\text {hitung }}$ & $\mathbf{r}_{\text {tabel }}$ & Keterangan \\
\hline $\mathrm{X} 1.1$ & 0,844 & 0,165 & Valid \\
\hline $\mathrm{X} 1.2$ & 0,903 & 0,165 & Valid \\
\hline $\mathrm{X} 1.3$ & 0,820 & 0,165 & Valid \\
\hline $\mathrm{X} 1.4$ & 0,803 & 0,165 & Valid \\
\hline
\end{tabular}

\section{Hasil Analisis Variabel Kualitas} Pelayanan (X2)

\begin{tabular}{|c|c|c|c|}
\hline Item & rhitung & rtabel & Keterangan \\
\hline X2.1 & 0,949 & 0,165 & Valid \\
\hline X2.2 & 0,656 & 0,165 & Valid \\
\hline X2.3 & 0,714 & 0,165 & Valid \\
\hline X2.4 & 0,847 & 0,165 & Valid \\
\hline X2.5 & 0,949 & 0,165 & Valid \\
\hline
\end{tabular}

\section{Hasil Analisis Variabel}

Peningkatan Penjualan (Y)

\begin{tabular}{|c|c|c|c|}
\hline Item & $\mathbf{r}_{\text {hitung }}$ & $\mathbf{r}_{\text {tabel }}$ & Keterangan \\
\hline Y1 & 0,748 & 0,165 & Valid \\
\hline Y2 & 0,876 & 0,165 & Valid \\
\hline Y3 & 0,805 & 0,165 & Valid \\
\hline Y4 & 0,632 & 0,165 & Valid \\
\hline Y5 & 0,610 & 0,165 & Valid \\
\hline
\end{tabular}

\section{Uji Reliabilitas}

Ghazali (2018:45) Uji reliabilitas sebenarnya adalah alat untuk mengukur 
suatu kuesioner yang merupakan indikator dari variabel atau konstruk. Suatu kuesioner dikatakan reliabel atau andal jika jawaban seseorang terhadap pernyataan adalah konsisten atau stabil dari waktu ke waktu. Untuk mengukur reliabilitas dengan uji statistik Cronbach Alpha ( a ) suatu konstruk atau variabel dikatakan reliabel atau andal jika memberikan nilai Cronbach Alpha > 0,70 .

Adapun kriteria pengujian reliabilitas menggunakan rumus Cronbach Alpha, yaitu :

1. Jika koefisien alpha $>0,70$ maka item variabel dapat dinyatakan reliabel.

2. Jika koefisien alpha $<0,70$ maka item variabel dapat dinyatakan tidak reliabel.

Hasil pengujian reliabilitas dapat dilihat pada tabel berikut ini:

\section{Hasil Pengujian Reabilitas}

\begin{tabular}{|c|c|c|}
\hline Variabel & $\begin{array}{c}\text { Cronbach } \\
\text { Alpha }\end{array}$ & Keterangan \\
\hline $\begin{array}{c}\text { Strategi } \\
\text { Pemasara } \\
\mathrm{n}(\mathrm{X} 1)\end{array}$ & $\begin{array}{c}0,862> \\
0,70\end{array}$ & Reliabel \\
\hline $\begin{array}{l}\text { Kualitas } \\
\text { Pelayanan } \\
\text { (X2) }\end{array}$ & $\begin{array}{c}0,886> \\
0,70\end{array}$ & Reliabel \\
\hline $\begin{array}{c}\text { Peningka } \\
\tan \\
\text { Penjualan } \\
\text { (X3) }\end{array}$ & $\begin{array}{c}0,792> \\
0,70\end{array}$ & Reliabel \\
\hline
\end{tabular}

Berdasarkan tabel diatas dapat dilihat bahwa semua variabel baik dependen maupun independen memiliki data yang reliabel terlihat dari nilai Cronbach Alpha lebih dari 0,70. dari data diatas maka penelitian ini bisa dilanjutkan.

\section{Uji Multikolonieritas}

Ghozali menguji apakah model ditemukan adanya kolerasi antar variabel bebas (independen). Model regresi yang baik seharusnya tidak terjadi kolerasi diantara variabel independen. Jika variabel independen saling berkolerasi, maka variabelvariabel ini tidak orthogonal. Variabel orthogonal adalah variabel independen yang nilai kolerasi antar sesama variabel independen sama dengan nol. Multikolonieritas dapat juga dilihat dari (1) nilai tolerance dan lawannya (2) variance inflation factor VIF).

Tolerance mengukur variabilitas variabel independen yang terpilih yang tidak dijelaskan oleh variabel independen lainnya. Jadi nilai tolerance yang rendah sama dengan nilai VIF tinggi (karena VIF $=1 /$ Tolerance). Untuk menunjukkan adanya multikolonieritas adalah :

Nilai Tolerance $<0.10$

Nilai VIF $>10$

Mengacu pada kedua pendapat diatas maka berdasarkan hasil penelitian yang telah dilakukan dapat diperoleh nilai :

\section{Hasil Uji Multikolonieritas}

\begin{tabular}{|c|c|c|c|}
\hline \multirow[b]{2}{*}{ Variabel } & $\begin{array}{l}\text { Collinear } \\
\text { ity }\end{array}$ & Statistics & \multirow[b]{2}{*}{$\begin{array}{c}\text { Kesimpul } \\
\text { an }\end{array}$} \\
\hline & $\begin{array}{c}\text { Toleranc } \\
\mathrm{e}\end{array}$ & VIF & \\
\hline $\begin{array}{l}\text { Strategi } \\
\text { Pemasar } \\
\text { an }\end{array}$ & ,312 & 3,205 & $\begin{array}{l}\text { Tidak } \\
\text { terjadi } \\
\text { multikol } \\
\text { onieritas }\end{array}$ \\
\hline $\begin{array}{l}\text { Kualitas } \\
\text { Pelayana } \\
\text { n }\end{array}$ & ,312 & 3,205 & $\begin{array}{l}\text { Tidak } \\
\text { terjadi } \\
\text { multikol } \\
\text { onieritas }\end{array}$ \\
\hline
\end{tabular}

Berdasarkan hasil tersebut maka dalam model regresi tidak terjadi multikolonieritas atau kolerasi yang sempurna antara variabel bebas, yaitu strategi pemasaran dan kualitas pelayanan karena nilai Tolerance $<0,10$ dan VIF > 10. 


\section{Uji Autokorelasi}

Ghozali (2018:111) Uji autokorelasi bertujuan untuk menguji apakah dalam model regresi linier ada korelasi antara kesalahan pengganggu pada periode $t$ dengan kesalahan pengganggu pada periode t-1 (sebelumnnya). Autokorelasi dapat dideteksi dengan menggunakan uji Durbin-Watson (DW test). Uji DurbinWatson hanya digunakan untuk autokorelasi tingkat satu dan mensyaratkan adanya konstanta dalam model regresi dan tidak ada variabel independen.

$0<\mathrm{dw}<\mathrm{dl} \quad$ : $\quad$ Tidak ada autokorelasi positif

$\mathrm{dl} \leq \mathrm{dw} \leq \mathrm{du} \quad$ : $\quad$ Tidak $\quad$ ada autokorelasi positif

$4-\mathrm{dl}<\mathrm{dw}<4 \quad$ : $\quad$ Tidak ada autokorelasi negatif

$4-\mathrm{du} \leq \mathrm{dw} \leq 4-\mathrm{dl}$ : Tidak ada autokorelasi negatif

$\mathrm{du}<\mathrm{dw}<4-\mathrm{dw} \quad$ : $\quad$ Tidak ada autokorelasi positif atau negatif

Berikut hasil uji autokorelasi dibawah ini :

\section{Hasil Autokorelasi}

Dapat dilihat dalam tabel diatas Durbin Watson dalam penelitian ini adalah 2.756 sedangkan $\mathrm{dl}=1.627$. jadi dapat dilihat dalam pengambilan keputusan yaitu tidak ada autokolerasi negati $4-\mathrm{dl}<\mathrm{dw}<4$ sama dengan $4-$ $2.756<1.627<4$.

\section{Uji Heteroskedastisitas}

Ghozali (2018:137) uji heterokedastisitas bertujuan untuk menguji apakah model regresi terjadi ketidaksamaan variance dari residual satu pengamatan ke pengamatan yang lain. Uji heteroskedastisitas dapat dilakukan dengan 2 cara yaitu :

a. Untuk mendeteksi ada atau tidaknya heteroskedastisitas adalah dengan melihat grafik plot antara nilai prediksi variabel terikat (dependen) yaitu ZPRED dengan residual
SRESID. Deteksi ada tidaknya pola tertentu pada grafik scatterplot antara SRESID dan ZPRED dimana sumbu $Y$ adalah $Y$ yang telah diprediksi, dan sumbu $\mathrm{X}$ adalah residual ( $\mathrm{Y}$ prediksi, dan sumbu $\mathrm{X}$ adalah residual ( $\mathrm{Y}$ prediksi - Y sesungguhnya) yang telah di studentized.

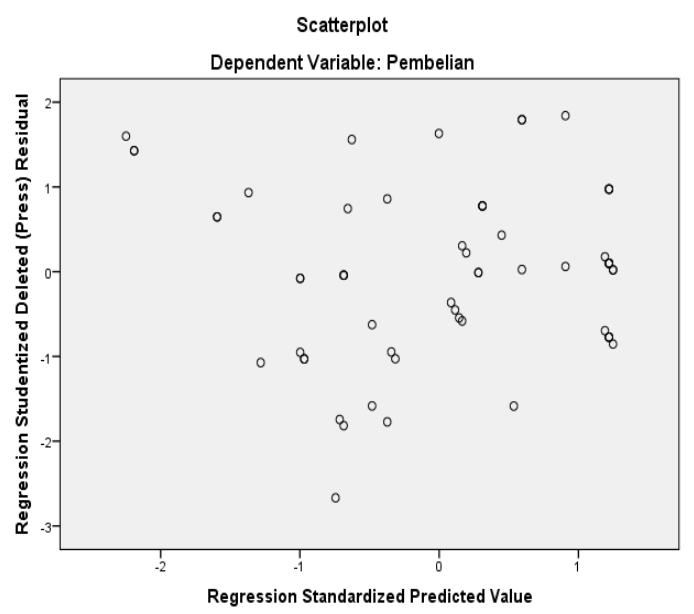

Gambar Scatterplot Heterokedastisitas

Dari gambar diatas hasil uji heterokedastisitas secara scatterplot titik-titik menyebar secara acak di atas maupun dibawah angka 0 dan

\begin{tabular}{|c|c|c|c|c|}
\hline \multirow[b]{2}{*}{$\mathrm{R}$} & \multirow{2}{*}{$\begin{array}{l}\mathrm{R} \\
\text { Square }\end{array}$} & \multirow{2}{*}{$\begin{array}{l}\text { Adjusted R } \\
\text { Square }\end{array}$} & $\begin{array}{l}\text { Std. Error of } \\
\text { the Estimate }\end{array}$ & \multirow{2}{*}{$\begin{array}{l}\text { Durbin } \\
\text { Watson }\end{array}$} \\
\hline & & & & \\
\hline $\begin{array}{l}.937 \\
\mathrm{a}\end{array}$ & .877 & .873 & 1.167 & 2.756 \\
\hline
\end{tabular}
menunjukkan bahwa tidak terjadi heterokedastisitas pada model regresi.

Dengan demikian, model regresi ini layak dipakai untuk variabel strategi pemasaran dan kualitas pelayanan terhadap peningkatan penjualan.

Uji Heterokedastisitas Secara Glejser, adalah mengusulkan untuk meregresi nilai absolute residual terhadap variabel independen. Residual adalah selisis antara nilai observasi dengan nilai prediksi, dan absolut adalah nilai mutlaknya. Jika nilai signifikan antara variabel independen dengan 
residu > 0,05 maka tidak terjadi heteroskedastisitas.

\section{Uji Normalitas}

Ghozali

(2018:161) Uji normalitas bertujuan untuk menguji apakah dalam model regresi, variabel pengganggu atau residual memiliki sitribusi normal. Seperti diketahui bahwa uji $\mathrm{T}$ dan $\mathrm{F}$ mengasumsikan bahwa nilai residual mengikuti distribusi normal. Kalau asumsi ini dilanggar maka uji statistik menjadi tidak valid untuk jumlah sampel kecil. Ada dua cara untuk mendeteksi apakah residual berdistribusi normal atau tidak yaitu dengan analisis grafik. Analisis grafik merupakan salah satu cara termudah untuk melihat normalitas residual adalah dengan melihat penyebaran data (titik) pada sumbu diagonal grafik. Dasar pengambilan keputusan :

- Jika data menyebar disekitar sumbu diagonal grafik dan mengikuti arah garis diagonal, maka model regresi memenuhi asumsi uji normalitas.

- Jika data menyebar jauh dari sumbu diagonal grafik dan tidak mengikuti arah garais diagonal, maka model regresi tidak memenuhi asumsi uji normalitas.

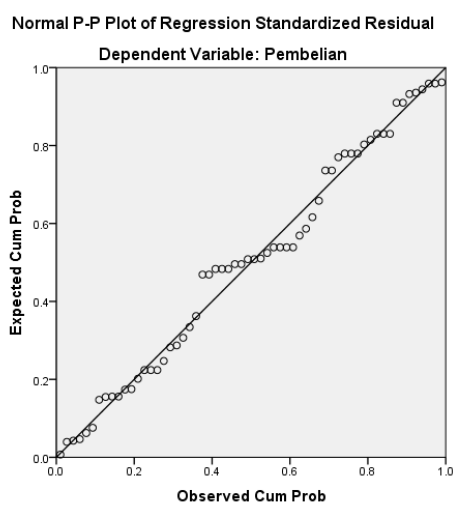

Gambar Normal Plot

Berdasarkan hasil diatas dapat diketahui bahwa data menyebar disekitar sumbu diagonal grafik dan mengikuti arah garis diagonal, maka model regresi memenuhi uji normalitas.

Hasil Uji Analisis Regresi Linier
Berganda
\begin{tabular}{|l|l|l|l|}
\hline & $\begin{array}{l}\text { Unstandardize } \\
\text { d Coefficients }\end{array}$ & $\begin{array}{l}\text { Standardize } \\
\text { Coefficients }\end{array}$ \\
\cline { 2 - 4 } & Etr. & Beta \\
\hline Model & $\mathrm{B}$ & Error & \\
\hline $\begin{array}{l}\text { (Constant) } \\
\text { Strategi }\end{array}$ & 4.327 & .795 & \\
$\begin{array}{l}\text { Pemasaran } \\
\text { Kualitas } \\
\text { Pelayanan }\end{array}$ & .869 & .085 & .849 \\
\hline
\end{tabular}

Berdasarkan tabel diatas dapat diperoleh rumus regresi sebagai berikut :

$\mathrm{Y}=4,327+0,869 \mathrm{X}_{1}+0,089 \mathrm{X}_{2}+\mathrm{e}$

Keterangan dari regresi diatas adalah sebagai berikut :

$\mathrm{a} \quad=4,327$ konstanta menunjukkan bahwa jika variabel penempatan Strategi Pemasaran (X1) Kualitas pelayanan (X2) bernilai 0 maka nilai variabel Pembelian (Y) sebesar 4.327

$\mathrm{b}_{1}=$ Strategi Pemasaran (X1) terhadap variabel Pembelian (Y) nilai koefisien strategi pemasaran untuk variabel X1 sebesar 0,869 dan bertanda positif. dapat diartikan bahwa setiap kenaikan strategi pemasaran satu-satuan maka variabel pembelian (Y) akan naik sebesar 0,869 dengan asumsi bahwa variabel bebas yang lain dari model regresi adalah tetap.

$\mathrm{b}_{2}=$ Kualitas pelayanan (X2) terhadap variabel Pembelian (Y). nilai koefisien kualitas pelayanan variabel X2 sebesar 0,869 dan bertanda positif. dapat diartikan bahwa setiap kenaikan kualitas pelayanan satu-satuan maka variabel pembelian (Y) akan naik sebesar 0,089 dengan asumsi bahwa variabel bebas yang lain dari model regresi adalah tetap.

Diantara variabel Strategi Pemasaran (X1) dan Kualitas pelayanan 
(X2) yang lebih berpengaruh terhadap variabel Pembelian (Y) adalah varaiabel Strategi Pemasaran (X1) dengan nilai koefisien sebesar 0,869 .

\section{Uji t (Parsial)}

\begin{tabular}{|c|c|c|}
\hline \multirow[b]{2}{*}{ Model } & $\begin{array}{c}\text { Standardized } \\
\text { Coefficients }\end{array}$ & \\
\hline & Beta & T \\
\hline $1 \quad$ (Constant) & & 5.445 \\
\hline $\begin{array}{l}\text { Strategi } \\
\text { Pemasaran }\end{array}$ & .849 & 10.218 \\
\hline $\begin{array}{l}\text { Kualitas } \\
\text { Pelayanan }\end{array}$ & .103 & 1.241 \\
\hline
\end{tabular}

Hasil pengujian dapat dinyatakan sebagai berikut :

- Apabila Ho diterima jika nilai hitung statistic uji ( $t_{\text {hitung }}$ ) berada didaerah permintaan. Apabila $t_{\text {hitung }}<t_{\text {tabel }}$, berarti Ho diterima dan $\mathrm{Ha}$ ditolak (tidak berpengaruh) yang artinya variabel independen secara signifikan tidak berpengaruh variabel dependen.

- Apabila Ho ditolak jika nilai hitung statistic uji ( $\left.t_{\text {hitung }}\right)$ berada didaerah penolakan. Apabila $t_{\text {hitung }}>t_{\text {tabel, }}$ berarti Ho ditolak dan Ha diterima (berpengaruh) yang artinya variabel independen secara signifikan berpengaruh variabel dependen.

Berdasarkan tabel 4.33 diatas, bahwa tingkat signifikan sebesar 0,05. Kemudian $\mathrm{N}=98, \quad \mathrm{~N}-\mathrm{k}-1=95$, jadi didapatkan hasil $t_{\text {tabel }}$ sebesar 1,290. Dapat dilihat nilai thitung 10,218 untuk variabel Strategi Pemasaran (X1) sebesar 10,218 sedangkan Kualitas Pelayanan (X2) sebesar 1.241.

\section{Hasil uji t Variabel Strategi Pemasaran (X1)}

Pada tabel 4.33 diatas terbaca nilai thitung untuk variabel Strategi Pemasaran sebesar 10,218 sedangkan $t_{\text {tabel }}$ adalah 1,290 dari hasil tersebut menunjukkan $t_{\text {hitung }} 10,218>t_{\text {tabel }} 1,290$ Maka dapat disimpulkan bahwa diferensiasi produk secara parsial terdapat pengaruh strategi pemasaran di PT. Ayu Indah Group cabang Paciran Lamongan.

Hasil Uji t Variabel Kualitas pelayanan (X2)

Pada tabel 4.34 diatas terbaca nilai

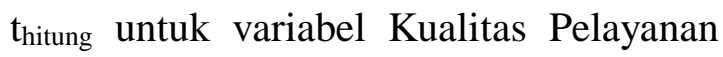
sebesar 1,241 sedangkan tabel adalah 1,290 dari hasil tersebut menunjukkan thitung $1,241>t_{\text {tabel }}$ 1,290. Maka dapat disimpulkan bahwa variabel Kualitas Pelayanan secara parsial terdapat pengaruh terhadap Variabel Pembelian pada perusahaan.

Uji F

Tabel Uji F (Simultan)

\begin{tabular}{|rl|r|r|l|}
\hline \multicolumn{2}{|l|}{ Model } & Df & \multicolumn{1}{|c|}{$\begin{array}{c}\text { Sean } \\
\text { Square }\end{array}$} & \multicolumn{1}{c|}{ F } \\
\hline 1 & Regressi & 2 & 277.022 & 203.465 \\
on & 57 & 1.362 & \\
Residual & 59 & & \\
& Total & 59 & \\
\hline
\end{tabular}

Uji $F$ digunakan untuk mengetahui pengaruh secara bersama-sama (simultan) atas variabel strategi pemasaran dan kualitas pelayanan terhadap peningkatan penjualan di PT. Ayu Indah Group

Jika $F_{\text {hitung }}<\mathrm{F}_{\text {tabel }}$ maka Ho diterima

Jika $F_{\text {hitung }}>F_{\text {tabel }}$ maka Ho ditolak.

Dapat diketahui diatas bahwa df $1=2$, df $2=57$ maka didapatkan $F_{\text {tabel }} 3.09$.

Dari hasil pengolahan data menggunakan SPSS 22.0, diperoleh hasil uji F dibawah ini :

Dari tabel 4.35 diatas dapat diperoleh $F_{\text {hitung }} 203,456>F_{\text {tabel }} 3,09$ pada taraf signifikan antara variabel bebas terhadap vaeriabel terikat. Dengan kriteria dan hasil pengujian diatas dapat dikatakan bahwa pada uji F Ho ditolak dan Ha diterima. Sesuai hipotesis yang kedua diduga terdapat berpengaruh yang signifikan antara strategi pemasaran dan kualitas pelayanan terhadap peningkatan penjualan di PT. Ayu Indah Group. 
Untuk hipotesis yang diduga bahwa berpengaruh strategi pemasaran dominan terhadap peningkatan penjualan di PT. Ayu Indah Group. Didapatkan hasil penelitian bahwa pengaruh yang lebih dominan adalah variabel strategi pemasaran. Hal ini ditunjukan oleh nilai koefisien $b_{1}$ sebesar 0,869 pada uji regresi linier berganda.

\section{Hasil Uji Koefisien Determiasi $\left(\mathbf{R}^{\mathbf{2}}\right)$}

\begin{tabular}{|l|c|r|r|c|}
\hline Model & $\mathrm{R}$ & $\begin{array}{r}\mathrm{R} \\
\text { Square }\end{array}$ & $\begin{array}{c}\text { Adjusted } \\
\mathrm{R} \\
\text { Square }\end{array}$ & $\begin{array}{c}\text { Std. } \\
\text { Error of the } \\
\text { Estimate }\end{array}$ \\
\hline 1 & $\begin{array}{r}.937 \\
\mathrm{a}\end{array}$ & .877 & .873 & 1.167 \\
\hline
\end{tabular}

Hal ini dapat diketahui bahwa peningkatan pembelian dipengaruhi oleh strategi pemasaran dan kualitas pelayanan sebesar $88,0 \%$ dan sisanya $12,0 \%$ dipengaruhi variabel lain yang tidak diteliti.

\section{Pembahasan}

1. Variabel strategi pemasaran secara parsial berpengaruh positif dan signifikan terhadap pelayanan terhadap peningkatan penjualan di PT. Ayu Indah Group Lamongan.

Hal ini dibuktikan dari hasil uji $\mathrm{t}$ diperoleh hasil $t_{\text {hitung }} 10,218$ dan $t_{\text {tabel }}$ sebesar 1,290. Jadi thitung 10,218> $t_{\text {tabel }} 1,290$ dengan signifikan $0,018<$ 0,05 . maka artinya strategi pemasaran secara parsial berpengaruh positif dengan signifikan terhadap peningkatan penjualan di PT. Ayu Indah Group cabang Paciran Lamongan.

2. Variabel kualitas pelayanan secara parsial berpengaruh positif dan signifikan terhadap peningkatan penjualan di PT. Ayu Indah Group Cabang Paciran Lamongan.
Hal ini dibuktikan dari hasil uji $\mathrm{t}$ diperoleh hasil thitung sebesar 1,241 dan $t_{\text {tabel }}$ sebesar 1,290 jadi $t_{\text {hitung }}$ $1,241>t_{\text {tabel }} 1,290$ dengan signifikan $0,000>0,05$ maka artinya inovasi produk secara parsial berpengaruh positif dengan signifikan terhadal peningkatan penjualan di PT. Ayu Indah Group.

3. Variabel strategi pemasaran dan kualitas pelayanan secara simultan berpengaruh terhadap peningkatan penjualan di PT. Ayu Indah Group. Hal ini dibuktikan dari hasil perhitungan uji $\mathrm{F}$ dapat diketahssui besarnya $F_{\text {hitung, }}$ sebesar 203,465 sedangkan $F_{\text {tabel }}$ sebesar 3,09. Jadi $F_{\text {hitung }} 203,465>F_{\text {tabel }} 3,09$. Hal ini membuktikan bahwa strategi pemasaran dan kualitas pelayanan secara bersama-sama (simultan) mempunyai pengaruh terhadap peningkatan penjualan di PT. Ayu Indah Group cabang Paciran Lamongan.

4. Untuk hipotesis yang diduga bahwa berpengaruh strategi pemasaran dominan terhadap peningkatan penjualan di PT. Ayu Indah Group. Didapatkan hasil bahwa pengaruh yang lebih dominan adalah variabel diferensiasi produk, hal ini ditunjukkan oleh nilai koefisien $b_{1}$ sebesar 0,869 pada uji regresi linier berganda.

\section{KESIMPULAN DAN SARAN}

\section{Kesimpulan}

Berdasarkan uji hipotesis pada hasil penelitian yang sudah dilakukan tentang Strategi Pemasaran dan Kualitas Pelayanan terhadap Peningkatan Penjualan di PT. Ayu Indah Group Cabang Paciran Lamongan, diperoleh beberapa kesimpulan sebagai berikut :

1. Strategi pemasaran berpengaruh pada signifikan dan positif 
terhadap peningkatan pembelian. Hasil penelitian yang dilakukan dengan membuktikan bahwa hasil perhitungan ini menunjukkan hubungan positif dan signifikan secara parsial antara variabel strategi pemasaran dengan peningkatan pembelian, sehingga hipotesisnya Ho diterima dan Ha ditolak. Dapat dilakukan dengan memberikan strategi pemasaran dengan baik sehingga bisa meningkatkan pembelian di PT. Ayu Indah Group.

2. Kualitas pelayanan berpengaruh pada signifikan dan positif terhadap peningkatan pembelian. Hasil penelitian yang dilakukan dengan membuktikan bahwa hasil perhitungan ini menunjukkan hubungan positif dan signifikan secara parsial atau antara kualitas pelayanan dengan peningkatan pembelian, sehingga hipotesisnya Ho diterrima dan Ha ditolak. Dapat dilakukan dengan memberikan kualitas pelayanan yang baik oleh perusahaan sehingga konsumen bisa tertarik dan konsumen menjadi banyak dan dapat meningkatkan pembelian di PT. Ayu Indah Group.

3. Variabel strategi pemasaran dan kualitas pelayanan secara simultan berpengaruh terhadap meningkatkan pembelian di PT. Ayu Indah Group.

Strategi pemasaran Hasil penelitian yang dilakukan membuktikan bahwa hasil perhitungan ini menunjukkan positif dan signifikan secara simultan antara variabel strategi pemasaran, kualitas pelayanan dan meningkatkan pembelian di PT. Ayu Indah Group.
5. Untuk hipotesis yang diduga bahwa berpengaruh strategi pemasaran dominan terhadap peningkatkan pembelian di PT. Ayu Indah Group. Didapatkan hasil penelitian bahwa pengaruh yang lebih dominan adalah variabel strategi pemasaran, hal ini ditunjukan oleh nilai koefisien $b_{1}$ sebesar 0,869 pada uji regresi linier berganda.

\section{Saran}

Berdasarkan kesimpulan tersebut maka saran yang diberikan adalah sebagai berikut :

1. Bagi perusahaan, perlu lebih ditingkatkan lagi strategi pemasaran perusahaan, agar perusahaan dapat meningkat jumlah pembelian. Pada variabel kualitas pelayanan, apabila PT. Ayu Indah Group Cabang Paciran terus memberikan pelayanan yang baik sesuai dengan indikator-indikator yang telah disebutkan dalam skripsi ini, maka konsumen merasa senang dan pembelian yang dilakukan konsumen akan meningkat.

2. Untuk bagi peneliti selanjutnya, alankah baiknya apabila memperluas variabel yang diamati. Misalnya dengan menambah variabel kepercayaan, fitur, dan sebagainya. Dengan harapan penelitian selanjutnya dapat lebih baik.

3. Pimpinan juga sebaiknya lebih mendengarkan pendapat dari konsumen. Sehingga pendapat tersebut dapat menjadi saran yang baik untuk kemajuan PT. Ayu Indah Group Cabang Paciran.

\section{DAFTAR PUSTAKA}

Sairo, Hesti, dkk (2018), Pengaruh Strategi Pemasaran Terhadap Peningkatan Penjualan Ikan Kaleng Isabella Pada PT. Sinar 
Mas Purefoods Internasional Bitung) (Online), Jurnal Administrasi Bisnis Vol. 6 No. 3

Rusdi, Moh (2019), Pengaruh Strategi Pemasaran Untuk Meningkatkan Volume Penjualan Pada Perusahaan Genting UD. Berkah Jaya. (Online). Universitas Trunojoyo Madura JSMB Vol. 6 (2) 2019

Aprida Riani, dkk, (2019), Pengaruh Produk, Harga dan Kualitas Layanan Terhadap Keputusan Pembelian Konsumen (studi Kasus Pada Toko Kain Kiloan Aulia Ponorogo) (Online), Universitas Muhammadiyah Ponorogo. Volume 3, No 1.

Sarini Kodu (2013), Harga, Kualitas Produk dan Kualitas Pelayanan Pengaruhnya Terhadapa Keputusan Pembelian Mobil Toyota Avanza. (Online). Universitas Sam Ratulangi Manado. Jurnal EMBA Vol. 1 No. 3

Jackson R.S. Weenas (2013), Kualitas Produk, Harga, Promosi Dan Kualitas Pelayanan Pengaruhnya Terhadap Keputusan Pembelian Spring Bed Compforta. (Online). Universitas Sam Ratulangi Manado. Vol. 1 No. 3

J.E. Sustanto, dkk. (2014), The Influence Service Quality Product Quality To Customer Satisfaction (A Case At Modern Riteil In East Java) (Online). Universitas Ciputra Surabaya. Volume 3, No 2.
Herwanzah, Fachrul, dkk (2019), Merketing Strategy Analysis To Increase Competitiveness In Nasional Ship Desain Industry. (Online). Universitas Of Airlangga Surabaya Indonesia. Vol. 5

Assauri, Sofyan. (2017), Manajemen Pemasaran, PT.Rajagrafindo, Jakarta.

Ghozali, Imam (2018), Aplikasi Analisis Multivariate Dengan Program IBM SPSS 25, Cetakan IX, Edisi 9, Universitas Diponegoro, Semarang.

Sugiyono, (2018), Metode Penelitian Kuantitatif, Kualitatif dan $R \& D$, Cetakan ke-27, Alfabeta, Bandung

Tjiptono, Fandy dan Diana Anastasia (2016), Pemasaran Esensi \& Aplikasi, Andi Offset, Edisi 1, Yogyakarta. Nasional"Veteran" Jawa Timur.

Alma, Buchari. (2018), Manajemen Pemasaran Dan Pemasaran Jasa, Edisi 1, Cetakan 13, Alfabeta, Yogyakarta.

Subagiyo Ali, Margo. (2016), Manajemen Pemasaran Jasa, Edisi 1, Cetakan 1, Deepublis, Yogyakarta.

Swastha, Basu. (2018), Manajemen Penjualan, Edisi 1, Cetakan 2, BPFE-YOGYAKARTA, Yogyakarta. 